\title{
AZ ELŐDÖK SZEREPVÁLLALÁSA AZ UTÓDLÁST KÖVETŐEN A CSALÁDI GAZDASÁGOKBAN KARCAGON
}

\author{
Kovács Éva Katalin
}

\begin{abstract}
Absztrakt: A legtöbb családi gazdaság a rendszerváltást követően jött létre, így az akkori alapítók többsége esetében a generációváltás kérdése aktuális témává vált. Az utódlás sikerességét számos tényező befolyásolja, többek között az utód hajlandósága az átvételre és az előd hajlandósága az átadásra. A gyakorlatban az tapasztalható, hogy az elődök többsége az utódlást követően is aktív szerepet tölt be a gazdaság életében. Néhány esetben azonban ez a túlzott ragaszkodás akadályozhatja az utódokat a fejlődésben. Ez hosszú távon akár motiválatlanná teheti az utódokat, amely veszélyeztetheti a családi gazdaságok jövőjét. Kutatásom során azt vizsgáltam, hogy a családi gazdaságokban hogyan alakul az elődök szerepvállalása Karcagon és erről az utódok hogyan vélekednek.
\end{abstract}

\begin{abstract}
Most family farms were established after the change of regime, therefore generational change has become a current issue for most of the founders. The success of generational change is influenced by several factors including the willingness of the successor to take over and the willingness of the predecessor to hand over. In practice, the majority of ancestors continue to play an active role in the life of the family farms after succession. In some cases, however, this excessive adherence may hinder development amongst successors. This may even make successors unmotivated on the long run, which may threaten the future of family farms. During my research, I examined how the role of ancestors in family farms in Karcag develops and how successors feel about it.
\end{abstract}

Kulcsszavak: generációváltás, nyomás, túlzott szerepvállalás, előd, utód

Keywords: generational change, pressure, over-involvement, ancestor, successor

\section{Bevezetés}

A családi gazdaságok legfőbb előnye, hogy akár generációkon át képesek egy család kezében maradni, ebből kifolyólag pedig több tíz évnyi tapasztalat és tudástőke összpontosulhat a vezetöjében (Makkos-Káldi et al., 2013; Vizdák et al., 2001). Ennek is köszönhetően a családi gazdaságok jelentősége a mezőgazdasági termelésben továbbra is igazolt (Harangi-Rákos et al., 2013), noha az adózás előtti eredmény jelentős részét a gazdasági társaságok realizálják (Szabó-Harangi-Rákos, 2011), ami az érintett szervezetek gazdálkodására is jelentős hatást gyakorol (Fenyves et al., 2019; Fenyves et al., 2020). A gazdaságok életében az egyik legfontosabb feladat ennek a vezetői szerepnek az átadása. Itt nemcsak jogi értelemben vett átadásról, hanem a döntéshozatal átadásáról beszélhetünk. Ezek a gazdaságok nagyfokú integritásról és értékekről tesznek tanúbizonyságot, továbbá fontosnak tartják a tudásátadást is (Tobak et al., 2018a). Ezekben a gazdaságokban nagy kihívást jelentenek a rokoni kapcsolatok, a család és a gazdaság kölcsönhatása, a tulajdonosok szerepe, a vezetés és a tulajdon öröklése. A családi gazdaságok generációváltása során a gazdaság vezetése a legtöbb esetben szülőről gyerekre öröklődik, ám bizonyos esetekben ettől eltérő rokonsági kapcsolatban lévő szereplők között is megvalósulhat az átadás. Alaphelyzetben az idős és a fiatal generáció (azaz az előd és az utód) között zajlik le a folyamat (Merwe, 2011). A felsorolt körülményekre tekintettel ennek a gazdálkodási formának a szerepét nem elegendő 
gazdasági szempontból vizsgálni, mindenképpen szem előtt kell tartani annak társadalmi vonatkozásait is (Harangi-Rákos-Szabó, 2013).

A családtagok közötti cserekapcsolatok alapvető fontosságúak a sikeres átmenet lebonyolításához és a harmónia megteremtéséhez (Bachkaniwala et al., 2001; Malone, 1989). A gyakorlatban akár kritikus is lehet a rokonok közötti viszonyrendszer, amelynek hatékony kezelésének eszköze a nyílt kommunikáció lehet (Kansikas-Kuhmonen, 2008). A Konczosné-Kézai szerint ezeknél a gazdaságoknál a sikeres müködés attól is függ, hogy a családtagok össze tudják-e hangolni megfelelően egymással a személyes érdekeiket, továbbá képesek-e alárendelni azokat a gazdaságuk érdekének (Konczosné-Kézai, 2018). Poza et al. (1997) véleménye alapján a szülők jelentős szerepet töltenek be az átvevők gazdaságról alkotott véleményében, ám nem minden esetben sikerül pozitív véleményt kialakíttatni az utódokkal. Az is előfordulhat, hogy a potenciális jelölt nem érdeklődik a gazdaság átvétele iránt (Stavrou, 1998), ami a fejlett országokban egyre gyakrabban előfordul (Herman et al., 2018; Fróna-Kőmíves, 2019). Ezért érdemes a fiatalokra hagyni a végső döntést, miszerint mennyire szeretnék bevonni magukat a vállalkozás müködésébe (Birley, 1986; Birley et al., 1999).

A generációváltás megtervezésének folyamatát nagyobb mértékben befolyásolhatják azok a családtagok, akik közelebbi rokonsági fokban állnak az aktuális tulajdonossal. Ezért azt is befolyásolják, hogy az utódlás milyen mértékben alapuljon a lojalitáson és a bizalmon (Davis-Harveston, 2001; Vallejo, 2008). Az utódlás megfelelö tervezése és elökészítése kulcsfontosságú a folyamat sikeressége és eredményessége szempontjából (Tobak et al., 2018b), amelyben megjelennek olyan családi szintü döntések, mint például a rokonság mezőgazdasági tanulmányainak finanszírozása annak érdekében, hogy az új tudásnak köszönhetően a gazdálkodás eredményessége javulhasson (Kömíves et al., 2019). A rokoni kapcsolatok jelentős szerepet játszanak az utódok fejlődésében. Egy egymással összetartó család erősíti az olyan cserekapcsolatokat, amelyek alapja a bizalmon és tisztelet (Lansberg-Astrachan, 1994; Seymour, 1993). Mindez Handler (1994) véleménye alapján nélkülözhetetlen a sikeres gazdaságátadás lebonyolításához. Ezzel teljes mértékben egyet tudok érteni, mivel úgy vélem, hogy egy összetartó családban nevelkedő utód sokkal nagyobb késztetést érez a gazdaság átvételére. Ez annak is köszönhetö véleményem szerint, hogy az elöd bizalmat szavaz az utódnak azzal, hogy bevonja őt a gazdaság tevékenységébe. Hazánkban a családi gazdaságok alapítása a rendszerváltást követően terjedt el, ezért az akkor alapított gazdaságok napjainkban érik el azt a kort amikor esedékes lehet a vezetőváltás (Laczkó, 1997). Ez alapvetően magába foglalhatja a jelenlegi vezető teljes visszavonulását, azonban azt tapasztalhatjuk, hogy az elödök az utódlást követően is szimbolikus szerepet töltenek be a gazdaság életében. Ezáltal pedig nagy hatást gyakorolnak a céges kultúrára, annak értékeire és teljesítményére (Miller et al., 2003; Csákné, 2012).

Összességében elmondható, hogy ugyan az elődök széleskörü tapasztalattal rendelkeznek a gazdálkodás folytatását tekintve, ám járatlanok az utódlás területén. Annak ellenére, hogy akár többük fejében megszületik a nyugdíjba vonulás gondolata, a tényleges megvalósításig csak nagyon kevesen jutnak el (Kovács, 
2020). Ebből kifolyólag 2 hipotézist állítottam fel, miszerint az elödök szerepe az utódlást követöen is jelentős marad (H1). Ez alatt azt értem, hogy a generációváltással az átadók nem feltétlenül vonulnak a háttérbe, befolyásolhatják a gazdaság vezetését és beleszólásuk lehet a döntéshozatalba. Ezzel megnehezítve az utódok helyzetét, ugyanis az elődök „,stafétabothoz való ragaszkodása” - azaz, hogy túlságosan kötődnek a saját tulajdonukhoz vagy a gazdaságukhoz (Mosolygó et al., 2018; Noszkay, 2017). Ez a ragaszkodás az irányításához jelentősen fékezheti a fiatalabb generáció kockázatvállalási hajlandóságát és fejlődési lehetőségeit (Kovács, 2020). A második hipotézisemben (H2) azt feltételeztem, hogy az elödök túlzott szerepvállalása hátráltathatja az utódokat a fejlödésben.

\section{Anyag és módszer}

Kutatásom során szekunder és primer kutatást egyaránt végeztem. Szekunder kutatásomban hazai és nemzetközi statisztikai adatbázisokat elemeztem, valamint értékelő szakirodalmi elemzést végeztem. A szekunder kutatásra alapozva pedig primer kutatásomként kérdőívet állítottam össze, melyet olyan családi gazdálkodók töltöttek ki, akiknél aktuális a generációváltás kérdése Karcagon. A kérdöíves megkérdeznél a reprezentativitásra törekedtem, ám végül összesen 143 gazdálkodóhoz sikerült eljutnom, így a vizsgált mintám eredményei csak Karcag gazdálkodóira vonatkoznak, de a mintám nem mondható reprezentatívnak, azonban mégis tükrözheti a családi gazdaságok valós véleményét az elődök szerepvállalásáról a generációváltást követően, mivel a családi gazdálkodók kb. 59\%-át sikerült felkeresnem. A kérdőívemet három kérdéscsoportra osztottam fel, a saját gazdaságukra vonatkozó általános kérdésekre, a családi gazdaságokról szóló és a sikeres generációváltáshoz szükséges tényezőkről szóló részre, végül pedig a magára a gazdálkodóra vonatkozó kérdéseket tettem fel. Az első két kategória kitöltése kötelező volt az elődök és az utódok számára is. Ezt követően azonban a gazdálkodók kiválaszthatták, hogy a gazdaságon belül milyen szerepet töltenek be (előd vagy utód). Itt a kérdőívem kettévált az átadóra és az átvevőre vonatkozó kérdésekre.

A kérdőív eredményeit Microsoft Excel 2019 és IBM SPSS 26 segítségével elemeztem. Az elemzések során nem paraméteres próbákat, kereszttábla elemzést valamint korrelációkat (Spearman-Pearson) végeztem. A skálák normalitásának tesztjéhez Kolmogorov-Szmirnov tesztet alkalmaztam (Malhotra, 2008). A kategorikus változók közti kapcsolatok vizsgálatához (Pearson-féle) Khi-négyzet próbát végeztem (Sajtos-Mitev, 2007). Több csoport közötti különbséget vizsgálatához medián próbát készítettem, majd a vizsgálati tényezők medián értékeit két egymástól függetlenül képzett csoportban a Mann-Whitney próba segítségével hasonlítottam össze (Fidy-Makara, 2005). Kettőnél több csoport összehasonlításához a Mann Whitney próbát kiterjesztettem Kruskal-Wallis elemzéssé (Leard Statistics, 2016). 


\section{Eredmények és értékelésük}

Az eredményeimet a megfogalmazott hipotéziseknek megfelelően mutatom be. H1 hipotézisem szerint az elödök szerepe a generációváltást követöen is jelentös marad. Ennek vizsgálatához elsőként felmértem az utódok félelmeit, miszerint:

Lehetséges, hogy az átadó nehezen engedi el a hatalmat és a döntéshozatalt?

Lehetséges, hogy az átadó nem bízik benne eléggé ahhoz, hogy teljes mértékben átadja számára a gazdaságot?

Ennek a 2 kérdésnek megvizsgáltam a gyakoriságát az utódok esetében. A leíró statisztika alapján az utódok 58,6\%-a úgy gondolja, hogy elödje nehezen engedi el a gazdaság vezetését. Az utódok 32,2\%-a szerint pedig elödje soha nem fogja teljesen átadni a családi gazdaságát, mivel nem bízik benne eléggé. Ezt követően megvizsgáltam, hogy a gazdaságokban ki látja el a vezetői feladatokat. Mint az látható, az esetek 20,5\%-ában az átadó az egyedüli vezető. A legtöbb esetben (58\%) közösen vezeti az előd és az utód a gazdaságot, és mindössze az utódok 11,4\%-a vezeti egyedül a családi gazdaságukat. Ennek eredményét az 1. ábra szemlélteti.

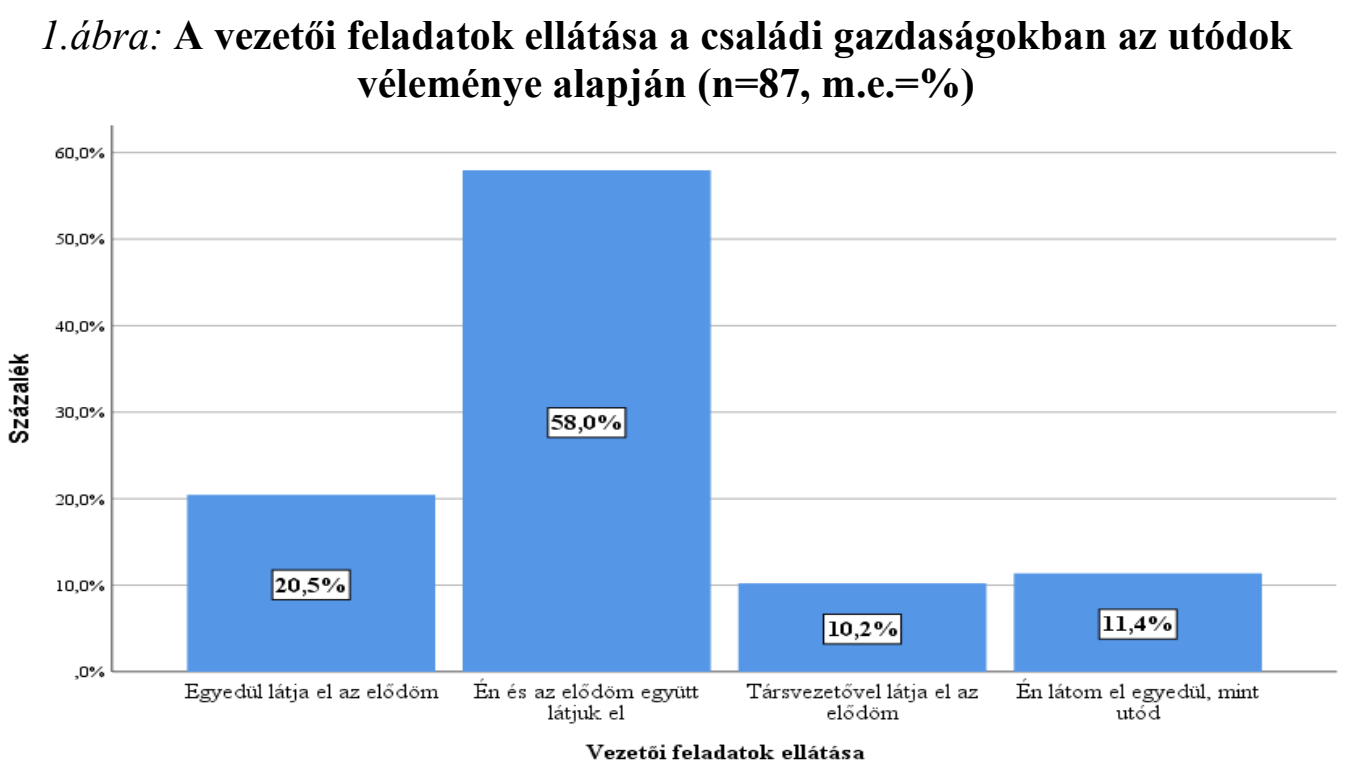

Forrás: Saját kutatás, 2021

A 2. ábra szemlélteti, hogy a döntéshozatalban milyen arányban vehetnek részt az átvevők. Látható, hogy az utódok az esetek 85,2\%-ában részt vehetnek a döntésekben, ennek ellenére (kifejezetten erre vonatkozó kérdés alapján) az utódok átlagos részvételi aránya a döntésekben mindössze 40-50\%. Megállapítható, hogy ugyan az esetek többségében kikérik az elödök az utódok véleményét, ám nem minden esetben van döntésüknek létjogosultsága. 


\section{2.ábra: Az utódok részvételi aránya a döntéshozatalban a családi gazdaságokban $(n=87$, m.e. $=\%)$}

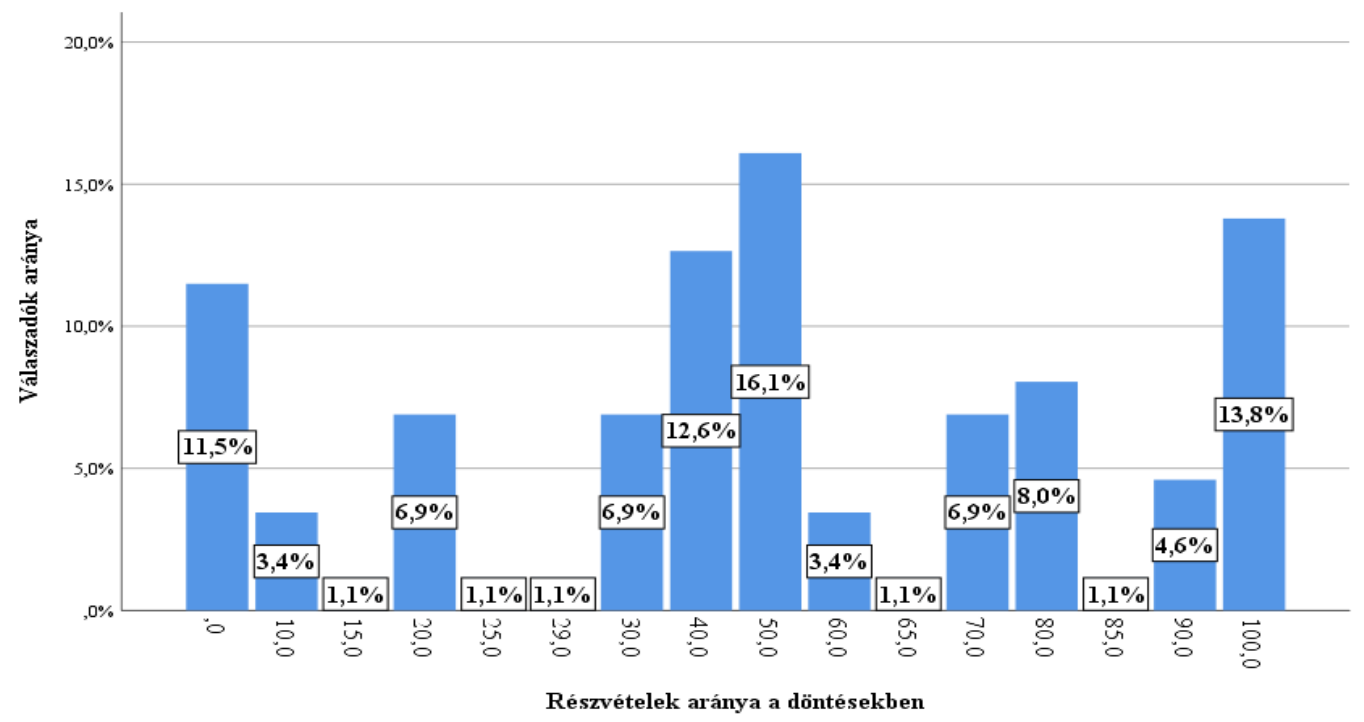

Forrás: Saját kutatás, 2021

A vizsgálat során felmértem az utódok életkorát, mely során arra jutottam, hogy a legfiatalabb utód 14 éves, míg a legidősebb 58 éves. Az átlag életkora az átvevők esetében 35 év körül alakult. Az utódok életkorát összevettetem a döntésekben való részvételek arányával. Erre azért volt szükség mivel azt feltételeztem, hogy az életkoruk ellenére sem biztos, hogy megfelelő mértékben részt vehetnek a döntésekben. Ehhez Pearson korrelációt készítettem, mely során korrelációt kaptam $(\mathrm{r}=0,531)$, szignifikáns eredménnyel $(\mathrm{p}<0,001)$. Vagyis (ahogyan azt a regressziós egyenes is mutatja) minél idősebbek az utódok annál inkább nagyobb a részvétel aránya a döntésekben. Ennek ellenére, mint ahogyan az a 3. ábrán is látható több olyan utód is van, akik akár 50 évnél is idősebbek mégsem vehetnek részt a döntésekben maradéktalanul. Sőt olyan utód is akad, aki mindössze 30-40\%-ban vehet részt és olyan is, aki egyáltalán nem.

$\mathrm{Az}$ utódok életkorát követően az elődökét vizsgáltam meg. Az átadók átlagéletkora 55 év, a legfiatalabb előd 28 éves, míg a legidősebb 82 éves (4. ábra).

Az életkor függvényében egy kereszttábla elemzés segítségével megvizsgáltam, hogy akarják-e folytatni a gazdálkodást. Elmondható, hogy az elődök 94,6\% folytatni kívánja a gazdálkodást és mindössze 3 fö szeretne visszavonulni. Ez a 3 fó mind 60 év feletti. Ezalapján megállapítható, hogy szinte egyik elöd sem szeretné úgy átadni gazdaságát, hogy ő maga ne folytatná tovább a gazdálkodást. Ehhez szorosan kapcsolódva megvizsgáltam a gazdaságátadás szakaszát. Röviden összefoglalva elmondható, hogy az általam megkérdezett családi gazdaságok 47,7\%ban a gazdaságátadás már folyamatban van és az utód az előddel közösen látja el a vezetői feladatokat. Az esetek 4,5\%-ában a gazdaságátadás már lezajlott, azonban az elöd még nem vonult vissza, és mindössze $11,4 \%$ azon esetek aránya, ahol már az 
elöd teljesen vissza is vonult. Tehát ebből is jól látható, hogy az elödök szerepe az utódlást követöen is valóban jelentös marad (Hla).

3. ábra: Az utódok életkorai és a döntésekben való részvételek arányai közötti összefüggések $(n=87$, m.e. $=\%)$

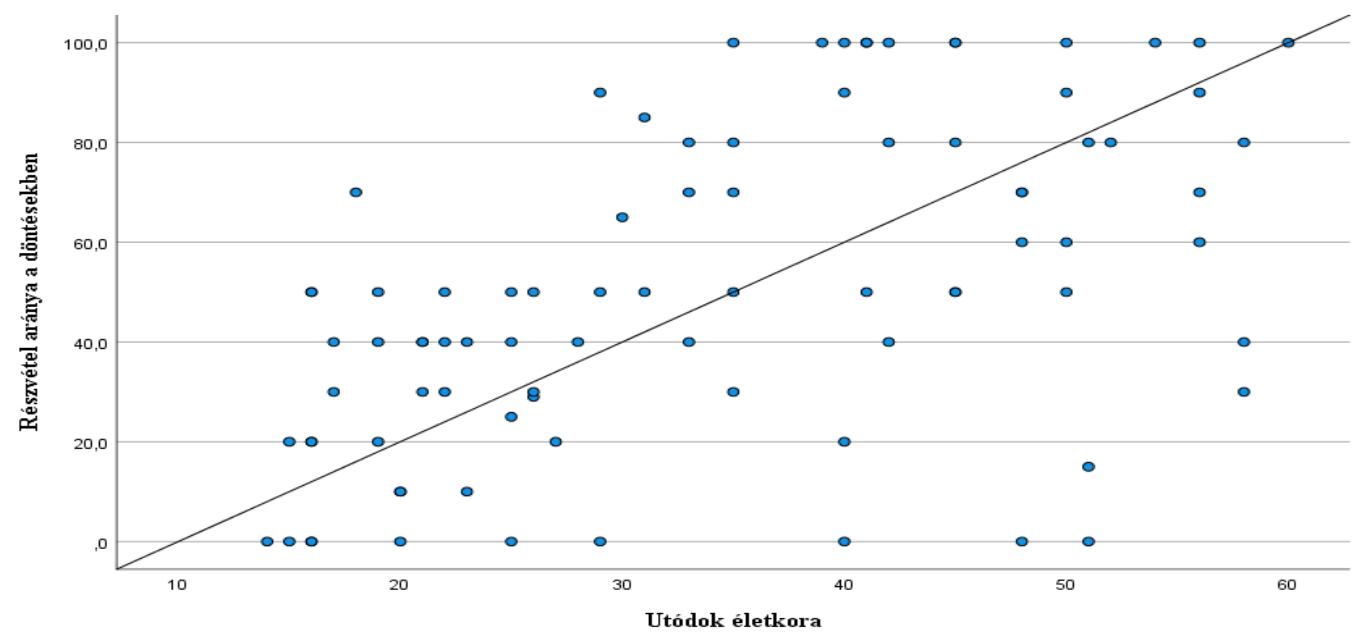

Forrás: Saját kutatás, 2021

4. ábra: Azon elödök életkorainak megoszlása, akik folytatni szeretnék a gazdálkodást $(\mathrm{n}=56, \mathrm{~m} . \mathrm{e} . \mathrm{fö})$

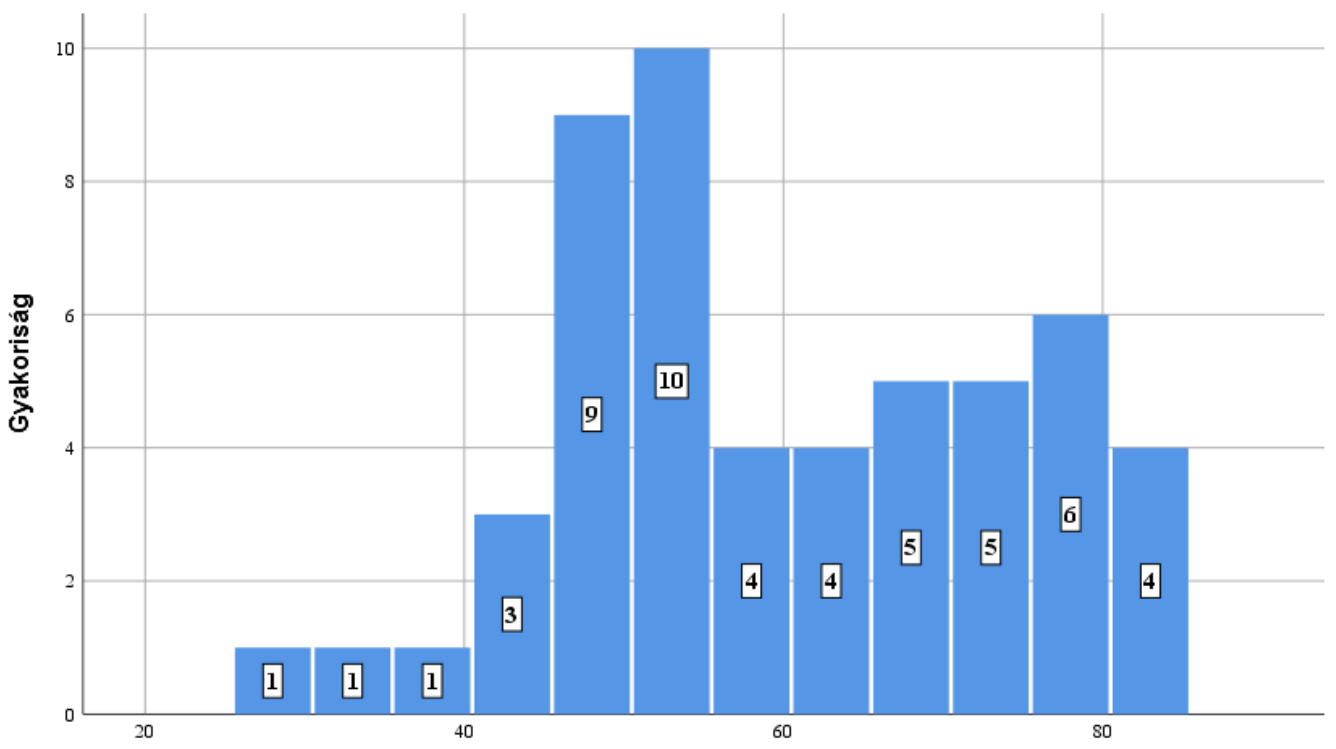

Elödök életkora

Forrás: Saját kutatás, 2021

H2 hipotézisemben azt feltételeztem, hogy az átadók túlzott szerepvállalása hátráltathatja az utódokat a fejlődésben. Kutatásom kezdetén úgy véltem, hogy az utódok fejlődését akadályozhatja az elődök ragaszkodása. Ezért megvizsgáltam az 
utódok félelmeit, miszerint az elöd túlzott ragaszkodás miatt nem valósíthatja meg saját terveit, valamint elödje nem bízik benne eléggé ahhoz, hogy teljesen átadja a gazdaságát, továbbá ide soroltam még azt az állítását is az utódoknak, hogy bátrabban hoznának döntéseket, ha csakis rajtuk múlna. Ezen túlmenően megvizsgáltam, hogy az előd folytatni kívánja-e a gazdálkodást. Megállapítható, hogy az utódok 37,9\%-a úgy gondolja, hogy nem valósíthatja meg terveit az elődje túlzott ragaszkodásának köszönhetően. Az utódok 32,2\%-a szerint pedig elődje nem bízik benne eléggé ahhoz, hogy teljesen átadja a családi gazdaságukat.

Megvizsgáltam a vezetői feladatok ellátásának és a gazdaságátadás szakaszának kapcsolatát egy Khi négyzet próba segítségével. Ennek eredményeképpen arra a következtetésre jutottam, hogy a megkérdezettek között összesen 10 olyan eset van, ahol az utód már átvette a vezetést és a vezetői feladatokat, így egyedül látja el a feladatokat, elödje segítsége nélkül. Abban az esetben, ha az átadás már zajlik, az esetek 90,5\%-ban az elöd ténylegesen az utóddal látja el a vezetői feladatokat, azonban akadt olyan válasz is, ahol inkább az előd vezeti továbbra is a gazdaságot. Összesen 4 olyan eset volt, amikor az utód már átvette a gazdaságot, de az előd még nem vonult vissza, ezekben az esetekben szintén közösen látták el. Azokban az esetekben, amikor még csak gondolkoznak az utódok az átvételen és tettek lépéseket vegyesen oszlik el a vezetés (30\%-csak az előd, 35\% az elöddel együtt, 30\% az előd társvezetővel látja el). Végül pedig, ahol még csak gondolkozik a gazdaság átvételén az utód, de nem tett lépéseket ott 66,7\%-ban még az előd egyedül vezeti a gazdaságot, 16,7\%-ban pedig vagy az utóddal együtt vagy egy társvezetővel látja el az előd a vezetői feladatokat. Vagyis minél inkább előrehaladott a gazdaságátadás szakasza, annál nagyobb az önállóság is az utód számára. Khi-négyzet $(12)=131,220$ $\mathrm{p}<0,001$, tehát szignifikáns kapcsolat mutatható ki.

Az utódok azon félelemét is megvizsgáltam, hogy az elődje ragaszkodása miatt nem valósíthatja meg a terveit összefüggésben van-e azzal, hogy hol tart a gazdaság átadása, illetve a vezetői feladatokat ki látja el. Ehhez elsőként egy kereszttáblaelemzést készítettem, melyből kiderült, hogy ha az átadás már folyamatban van, de az elöddel közösen vezetik a gazdaságot, akkor az utódok 58,5\%-a gondolta azt, hogy ez gátolja őket saját terveik megvalósításában. Amennyiben már átvette az utód a vezetést, azonban az előd még nem vonult vissza teljesen, akkor 50\%-a gondolja az utódoknak az elödök ragaszkodását hátráltatásnak. Akik még csak készülnek az átvételre kisebb arányban gondolják ezt akadályoztatásnak. Ez az eredmény szignifikáns $(\mathrm{p}=0,002)$.

Ezt követően a vezetői feladatok ellátásával vetettem össze hátráltatást egy Khinégyzet próba segítségével. Ennek eredményeként arra jutottam, hogy azok az utódok, akik már teljesen átvették a vezetést ott egyhangúan nem érzik az elődök hátráltatását. Ahol viszont az előd és az utód közösen vezeti a gazdaságot, ott az utódok 52,9\%-a gondolja úgy, hogy később sem valósíthatják meg saját terveiket. Ez az eredmény szintén szignifikáns értéket mutatnak $(\mathrm{p}=0,004)$.

Az elemzésem során az utódok azon félelmét vetettem össze a gazdaságátadás szakaszával, miszerint elődje nem bízik eléggé benne, ahhoz, hogy átadja teljesen gazdaságát. Khi-négyzet próba alapján arra a szignifikáns eredményre $(\mathrm{p}=0,007)$ 
jutottam, miszerint ahol az átadás már folyamatban van és az előd utódjával közösen vezeti a gazdaságot ott az utódok 48,8\%-a (20fö) gondolja azt, hogy nem fogja az elöd teljesen átadni a gazdaságot soha. Továbbá amennyiben az utód már átvette a gazdaságot, de az elöd nem vonult még vissza, az utódok 50\%-a vélekedik ugyanígy. Ugyanezt a félelmet a vezetői feladatok ellátásával is összevetettem egy Khi-négyzet próbán segítségével. A próba során ismét szignifikáns eredményt kaptam $(\mathrm{p}=0,006)$. Ez alapján megállapítható, hogy ha együtt dolgoznak, akkor az esetek 45,1\%-ában vélekednek negatívan az utódok. Illetve ez az arány akkor is magas, ha az előd társvezetővel együtt látja el a vezetői feladatokat (37,5\%).

Érdekességképpen megvizsgáltam azt is, hogy a bátrabb döntéshozatal hogyan függ össze a gazdaságátadás szakaszával és a vezetői feladatok ellátásával, ebben az esetben azonban (a Khi-négyzet próbákat elvégezve) nem kaptam szignifikáns különbségeket $(\mathrm{p}=0,931$ és $\mathrm{p}=0,877)$ egyik esetben sem. Tehát a döntéshozatal nincs összefüggésben a gazdaságátadás szakaszával és a vezetői feladatok ellátásával sem, ebből kifolyólag csakis az előző két szignifikáns eredményt ábrázoltam összehasonlítva (5. ábra).

\section{5. ábra: Összefüggések a vezetői feladatok ellátása és az utódok szignifikáns félelmei között (n=87, m.e.=\%)}

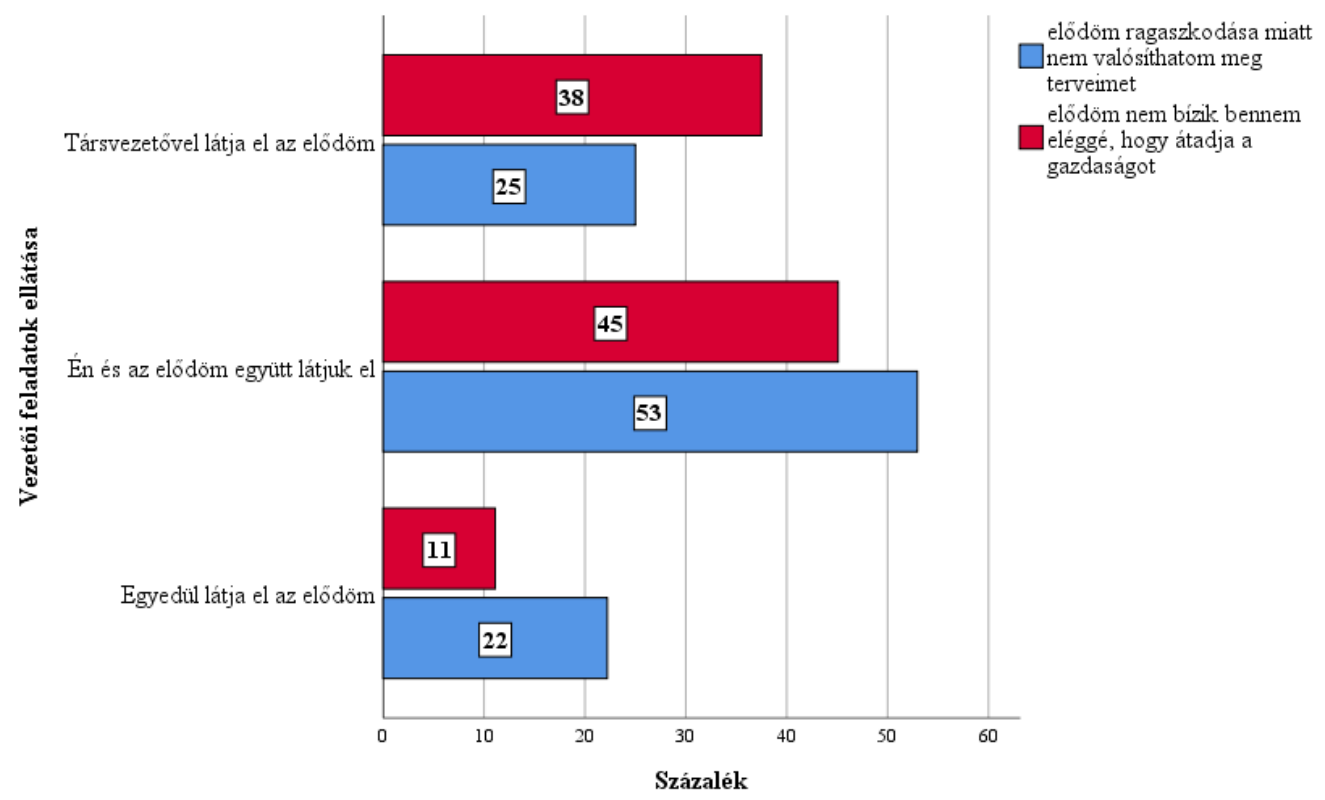

Forrás: Saját kutatás, 2021

Elmondható, hogy az utódok szignifikáns félelmei akkor a legerősebbek, amikor a két generáció közösen vezeti a gazdaságot. Továbbá elmondható, hogy az utódok számára nagyobb félelmet jelent, hogy nem valósíthatják meg terveiket. Amennyiben az elődök társvezetővel látják el a vezetői feladatokat, az utódok sokkal inkább attól félnek, hogy soha nem fogják megkapni teljes egészében a gazdaság 
vezetését. Így az utódok félelmeit a gazdaságátadás szakaszával vetettem össze, amelyet a 6 . ábra szemléltet.

\section{6. ábra: Az utódok szignifikáns félelmei és a gazdaságátadás szakaszainak összefüggései $(\mathrm{n}=87$, m.e. $=\%)$}

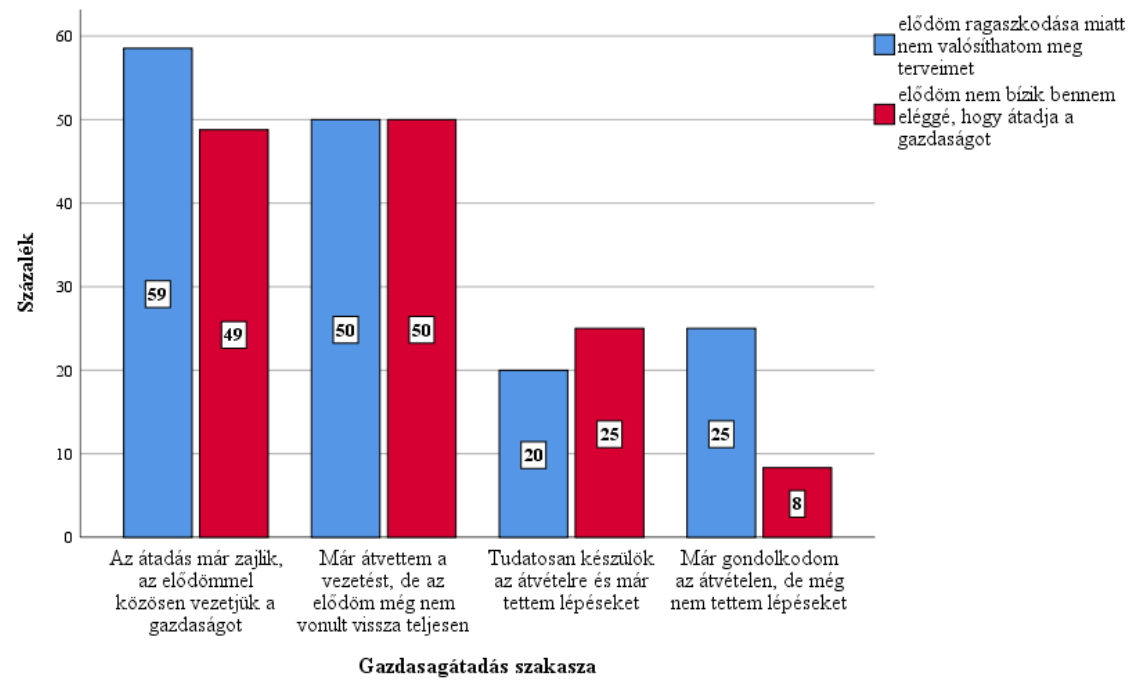

Forrás: Saját kutatás, 2021

Megállapítható, hogy ismét abban az esetben szkeptikusak az utódok, amikor közösen vezetik a gazdaságot az elöddel. Amennyiben az elöd átadta a vezetést, de még a visszavonulás nem történt meg az utódok úgy vélik ez a későbbiekben sem fog megtörténni. Ebből kifolyólag pedig attól félnek, hogy terveiket sem valósíthatják meg. Azonban, ha még az átadás nem történt meg és így vezetik a gazdaságot együtt az elöddel, akkor nagyobb az utódok félelme vonatkozóan, hogy nem a saját terveik szerint dönthetnek. Mindezek az eredmények igazolják, hogy $a z$ elödök túlzott szerepvállalása hátráltathatja az utódokat a fejlödésben.

\section{Következtetések, javaslatok}

A kutatásom során arra a kérdésre kerestem a választ, hogy miként alakul az elődök szerepe a generációváltást követően és ez mennyire akadályozza az utódokat a fejlődésben. A kérdőíves elemzéseket követően megállapítható, hogy az általam megkérdezett gazdaságokban leginkább az a jellemző, hogy az előd egyedül vagy utódjával közösen látja el a családi gazdaság vezetését.

A megkérdezett utódok az esetek 85,2\%-ában részt vehetnek a döntéshozatalban, azonban átlagos részvételi arányuk nem túl magas. Megállapítható továbbá, hogy minél idősebbek az utódok annál nagyobb a részvételük aránya a döntéshozatalban. Ennek ellenére több olyan eset is megfigyelhető, ahol az utód idős kora ellenére (50 év felett) sem vehetett részt a döntésekben. 
Az átadókról általánosságban elmondható, hogy életkortól függetlenül szinte senki sem szeretné átadni gazdaságát anélkül, hogy ő ne folytatná tovább a gazdálkodást aktívan. Ehhez szorosan kapcsolódik a gazdaságátadás szakasza, melyből szintén látszik, hogy az elődök szerepe valóban meghatározó. Mindezek alapján $H 1$ hipotézisemet elfogadom, mivel az elödök szerepe az utódlást követöen is jelentös marad.

H2 hipotézisemhez kapcsolódva összességében megállapítható, hogy az átvevők $37,9 \%$-a úgy véli nem valósíthatja meg terveit az elődje túlzott ragaszkodása miatt. Az utódok 32,2\%-a szerint, elödje nem bízik benne kellőképpen ahhoz, hogy a családi gazdaságot teljesen átadja. Ennek ellenére megfigyelhető, hogy minél inkább elörehaladott a gazdaságátadás szakasza, annál nagyobb az önállóság is az utód számára. A hátráltatástól való félelmek abban az esetben a legerősebbek, ha a két generáció párhuzamosan vezeti a családi gazdaságot. Továbbá az utódok sokkal inkább attól félnek, hogy nem valósíthatják meg terveiket. Amennyiben az elődök társvezetővel látják el a vezetést utódaik inkább attól félnek, hogy soha nem fogják teljes egészében átvenni a gazdaságot. Megállapítható tehát, hogy az átadók valóban fontos szerepet játszanak a gazdaságok életében (még a generációváltást követően is), továbbá az elődök túlzott ragaszkodása tényleges jelenség a gazdaságokban. Amennyiben az előd ezt túlzásba viszi valóban hátráltathatja az utódokat terveik megvalósításában. Ami legrosszabb esetben oda vezethet, hogy az utód nem szeretné tovább folytatni a családi gazdaságot, megpecsételve ezzel a gazdaság sorsát. Mindezek alapján $H 2$ hipotéziseimet szintén elfogadom.

Véleményem szerint az egyik legfontosabb feladat annak a felismertetése az elödökkel, hogy a hatalmat előbb vagy utóbb mindenképpen át kell adniuk. Úgy vélem ebben segíthetne a gazdálkodóknak a jó példák összegyüjtése, amelyből az elödök és az utódok is ihletet meríthetnének. Ezeket az összegyüjtött jó példákat érdemes egy kiadványban összesíteni és visszajuttatni a gazdálkodók felé gazdafórumokon és egyéb agrárrendezvényeken. Ahhoz, hogy lelkileg is felkészüljenek az átadásra az érintettek, úgy gondolom hasznos lehet, ha ezt megelőzően egy pár évet előbb közösen dolgoznának együtt. Amikor pedig az előd és az utód is úgy érzi, hogy eljött az ideje a generációváltásnak, akkor az elödöknek tudniuk kell a háttérbe vonulni és szabadabb kezet adni utódaiknak. Amíg azonban ezt az elödök nem érzik esedékesnek szükséges az utódok kitartása és türelme. Véleményem szerint érdemes lenne az utódok számára egy kisebb földterület biztosítása, ahol gyakorolhatnak és „kipróbálhatják magukat” egyedül is. Az elődök nyugodt visszavonulásához pedig véleményem szerint egy olyan életszínvonalat kell biztosítaniuk az utódoknak, amit életük során már megszoktak.

\section{Köszönetnyilvánítás}

A kutatás az EFOP 3.6.3-VEKOP-16-2017-00007 - "Tehetségböl fiatal kutató" - A kutatói életpályát támogató tevékenységek a felsőoktatásban. címü projekt keretében valósulhatott meg. 


\section{Irodalomjegyzék}

Bachkaniwala D., Wright M., Ram M. (2001): Succession in South- Asian businesses in the UK. International Small Business Journal, 9 (15).

Birley S. (1986): Succession in the family firm: The inheritor's view. Journal of Small Business Management, 24 (3): 36-43.

Birley S., Ng D., Godfrey, A. (1999): The family and the business. Long Range Planning, 32: 598608.

Csákné Filep J., Kása R., Radácsi L. (2018): Családivállalat-kormányzás a nemzetközi szakirodalom kategorizálása a három kör modell tükrében. Vezetéstudomány 49 (9): 46-56. Letöltés dátuma: 2018. szeptember 04. https://doi.org/10.14267/veztud

Davis P. S., Harveston, P. D. (2001): The phenomenon of subtantive conflict in the family firm: a cross generational study. Journal of Small Business Management. 39 (1).

Fenyves V., Pető K., Harangi-Rákos M., Szenderák J. (2019): A Visegrádi országok mezőgazdasági vállalkozásainak gazdasági és pénzügyi helyzete. Gazdálkodás, 63 (6): 459-473.

Fenyves, V., Pető, K., Szenderák, J., Harangi-Rákos, M. (2020): The capital structure of agricultural enterprises in the Visegrad countries. Agricultural Economics - Zemedelska Ekonomika, 66 (4): $160-167$.

Fidy J., Makara G. (2005): Biostatisztika, Informed 2002 Kft. Letöltés dátuma: 2020. március 24. http://www.tankonyvtar.hu/hu/tartalom/tkt/biostatisztika-1/ch08s03.html

Fróna D., Kőmíves P. M. (2019): A mezőgazdasági munkaerő sajátosságai. Gazdálkodás, 63 (5): 361-380.

Handler, W. C. (1994): Succession in family business: A review of the research. Family Business Review. 7: 133-157.

Harangi-Rákos, M., Szabó, G. (2013): The economic and social role of private farms in Hungarian agriculture. APSTRACT - Applied Studies in Agribusiness and Commerce, 6 (5): 33-41.

Harangi-Rákos M., Szabó G., Popp J. (2013): Az egyéni és társas gazdaságok gazdasági szerepének főbb jellemzői a magyar mezőgazdaságban. Gazdálkodás, 57 (6): 532-543.

Herman S., Körösparti P., Kőmíves P. M. (2018): A magyar agrár-felsőoktatás aktuális helyzete. International Journal of Engineering and Management Sciences, 3 (4): 263-281.

Kansikas, J., Kuhmonen, T. (2008): Family business succession: evolutionary economics approach. Journal of Enterprising Culture, 16 (3): 279-298. Letöltés dátuma: 2020. március 25. https://doi.org/10.1142/s0218495808000156

Konczosné Szombathelyi M., Kézai P. (2018): Családi vállalkozások - generációk és dilemmák. Prosperitas 2018 (3): 48-76. Letöltés dátuma: 2020. március 15. https://doi.org/10.31570/prosp_2018_03_3

Kovács É. K. (2020): Az idősebb korosztály szerepe a családi gazdaságok generációváltásában, Magyar Gerontológia 12 (38).

Kőmíves, P. M., Pilishegyi, P., Novák, N., Nagy, A. Sz., Körösparti, P. (2019): The role of the higher education in the development of the agriculture. International Journal of Information and Education Technology, 9 (9): 607-612.

Laczkó Zs. (1997): Családi vállalkozás - konfliktus és kooperáció. Budapest, CiPE, SEEd Alapítvány, 121-140.

Lansberg, I., Astrachan, J. (1994): The Influence of Family Relationships on Succession Planning and Training: The Importance of Mediating Factors. Family Business Review, 7 (1).

Leard Statistics (2016): Kruskal-Wallis H Test using SPSS Statistics. Letöltés dátuma: 2020. március 24. https://statistics.laerd.com/spss-tutorials/kruskal-wallis-h-test-using-spss-statistics.php

Makkos-Káldi J., Eisingerné Balassa B., Kecskés P. (2013): Aranyat ér-e az ezüstgeneráció? TérGazdaság Ember, 1 (1): 119-134.

Malhotra, N. K. (2008): Marketing Research: An Applied Orientation. Pearson Custom Publishing, $120-322$.

Malone, S. C. (1989): Selected correlates of business continuity planning in the family business. Family Business Review, 2 (4). 
Merwe, S. P. (2011): An investigation into the suitability of younger generation successors in small and medium-sized family businesses. South African Journal of Business Management, 42 (1): $31-44$.

Miller, D., Le Breton-Miller I. (2003): Challenge versus advantage in family business. Strategic Organization, 1 (1): 127-134.

Mosolygó Á., Csákné Filep K. J., Heidrich B. (2018): Do first swallows make a summer? - on the readiness and maturity of successors of family businesses in Hungary. Working paper series, 2018 (6).

Noszkay E. (2017): Tapasztalatok a családi vállalkozások átörökítésének dilemmái kapcsán. Vezetéstudomány-Budapest Management Review, 48 (6-7): 64-72. Letöltés dátuma:2017. június 08. https:doi.org/10.14267/VEZTUD.

Poza, E. J., Alfred T., Maheshwari A. (1997): Stakeholder perceptions of culture and management practices in family and family firms- a preliminary report. Family Business Review, 10 (2).

Sajtos, L., Mitev, A. (2007): SPSS kutatási és adatelemzési kézikönyv. Budapest, Alinea Kiadó, 13327.

Seymour, K. C. (1993): Intergenerational Relationships in the Family Firm: The Effect on Leadership Succession. Family Business Review, 6. évf.

Stavrou, E. T., Swiercz P. M. (1998): Securing the future of the family enterprise: a model of offspring intentions to join. Entrepreneurship: Theory and Practice, 23 (2): 19-39.

Szabó G., Harangi-Rákos M. (2011): A mezőgazdasági szervezetek gazdálkodásának vizsgálata a 2002-2009 közötti időszakban. Gazdálkodás, 55 (4): 358-366.

Tobak J., Nagy A. Sz., Pető K. - Fenyves V. -Nábrád A. (2018a): The main factors determining effective operation in case of a family business. International Journal Of Engineering And Management Sciences / Müszaki És Menedzsment Tudományi Közlemények 3 (3): 280-287.

Tobak, J., Nagy, A., Pető, K., Fenyves, V., Nábrádi, A. (2018b): The main factors determining effective operation in case of a family business. International Journal of Entrepreneurial Behaviour and Research 24 (6): 1065-1074.

Vallejo, M. C. (2008): Is the culture of family firms really different? A value-based model for its survival through generations. Journal of Business Ethics, 81 (2).

Vizdák K., Lakatos V., Király J. (2001): Mezőgazdasági családi vállalkozások Jász-NagykunSzolnok megyében. Gazdálkodás, 45 (3): 25-32. 